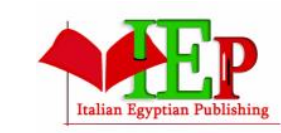

ISSN: $2735-4415$

\section{INTERNATIONAL JOURNAL OF \\ MULTIDISCIPLINARY STUDIES IN ARCHITECTURE AND CULTURAL HERITAGE}

VOLUME 1, ISSUE 1, 2018, 129 - 145.

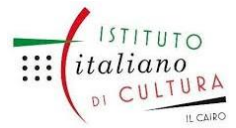

www.egyptfuture.org/ojs/

\title{
Microbiological Deterioration Survey of Historical Parchment in Different Institutions
}

\author{
Reda Farag a, Hany Gad b, *, Sara Ghazi c \\ a Director of conservation and preservation, Technical business company TBC, Tripoli, \\ Lebanon \\ b Conservator at Historic Cairo Administration Ministry of Antiquities, Egypt \\ c Laboratory responsible, Technical business company TBC, Tripoli, Lebanon
}

\begin{abstract}
The knowledge of our generations is based on the information and the historical documents that conserve all cultural value for humankind and race, this knowledge was transmitted from ancestral by writing material like parchment, which was made from animal skin. Furthermore, the essential components of parchment were the collagen, water, and inorganic materials. As others nutritive source these writing materials can be the target of many microorganisms especially the fungus.

A total of forty historical parchments were collected from different institution, twelve of them were suspected to be infected by microorganisms due to visible color change on the surface of the parchment. The sample collected by sterilized swabs on the different spot of suspected infected parchment, then the specimen cultured on sabouraud dextrose agar (Actidione®) for 7 days at $25 \stackrel{\circ}{c}$. The identification is based on the morphology of the colony on the agar and the microscopic observation. As results, after the incubation time at favourable temperature, eight of these twelve historical parchments have an active fungus infection with at least one genus. The detected fungi were respectively six Aspergillus niger, five Aspergillus flavus, three Fycomycetes, one Penicillium funiculosum, and one Trichoderma viride.

Finally, the microbial analysis of the infected manuscript which had kept in different national library identified four fungi genus. Further studies are required to identify the species of some fungi using a molecular method, and to study the mechanical effect of this infection on the components of parchment and their elasticity anduse approximately all the method of cleaning for eliminate the effect of fungus reaction on parchment.
\end{abstract}

\footnotetext{
Keywords

The knowledge of our generations is based on the information and the historical documents that conserve all cultural value for humankind and race, this knowledge was transmitted from ancestral by writing material like parchment, which was made from animal skin. Furthermore, the essential components of parchment were the collagen, water, and inorganic materials. As others nutritive source these writing materials can be the target of many microorganisms especially the fungus.

A total of forty historical parchments were collected from different institution, twelve of them were suspected to be infected by microorganisms due to visible color change on the surface of the parchment. The sample collected by sterilized swabs on the different spot of suspected infected parchment, then the specimen cultured on sabouraud dextrose agar (Actidioneß) for 7 days at $25 \stackrel{\circ}{c}$. The identification is based on the morphology of the colony on the agar and the microscopic observation. As results, after the incubation time at favourable temperature, eight of these twelve historical parchments have an active fungus infection with at least one genus. The detected fungi were respectively six Aspergillus niger, five Aspergillus flavus, three Fycomycetes, one Penicillium funiculosum, and one Trichoderma viride.

Finally, the microbial analysis of the infected manuscript which had kept in different national library identified four fungi genus.

Further studies are required to identify the species of some fungi using a molecular method, and to study the mechanical effect of
} 
INTERNATIONAL JOURNAL OF

MULTIDISCIPLINARY STUDIES IN ARCHITECTURE

AND CULTURAL HERITAGE

\section{Introduction}

The knowledge of our generations is based on the information and the historical documents that conserve all cultural value for humankind and race, this knowledgewas transmitted from ancestral, and can be found on parchment or other writing material depending on the century of this features. Furthermore, the parchment was used by Assyrian peoples as a writing materiel because the Aramaic script wasn't able to write in the clay tablets $(1,2)$.

In Europe and the Mediterranean the most used kind of writing material was theparchment because it have several advantages over the papyrus (the most ancient writing material), the parchment is able to resist the environmental conditions more than other type of writing material (good mechanical proprieties), can be used fromthe two sides, and alsoit can be reusable due to the ability of removing of the ink andre-writing on it again(3).

The parchment is made from animal skin, usually from calf, goat, camel or sheep, after a long treatment procedure(3). It is composed from water, inorganicmaterials and organic components like collagen type I or type III depending on the body parts or the type and the age of the animals $(4,5)$. The collagen is a fibrous proteinformed by a chain 
INTERNATIONAL JOURNAL OF

MULTIDISCIPLINARY STUDIES IN ARCHITECTURE

AND CULTURAL HERITAGE

of amino acids with abundance of glycine, proline, and hydroxyproline(3).

Like any nutritive sources the collagen can bedenaturated due to various agents as the biodegradation caused by microorganism vital activity which can hydrolyse the parchments components into disordered gelatine, and produce pigments and organic acids responsible of color change and indirect damage(6).

The mean microorganisms which can attack the writing material, especially the parchment or vellum, are the fungi and the bacteria, but the principal onesare the microfungi(7), which are widespread organisms and can be found anywhere becauseof their resisting forms (spores) that present in 20 thousand to 2 million fungus sporesin $1 \mathrm{~m}^{3}$ of air(8). These spores grow and spread when the environmental condition, like the temperature, $\mathrm{pH}$ and humidity, are favourable(9).

The results of microbial damage depending on the species that attack the parchment. The microorganism identification is usually based on phenotypic method like culture method and the microscopic observation.

The aim of this study was to determine the type of the microorganisms that cause infections and damage of 12 historical 
INTERNATIONAL JOURNAL OF

MULTIDISCIPLINARY STUDIES IN ARCHITECTURE

AND CULTURAL HERITAGE

parchments of a total 40 manuscripts stored in different institutions that contain important and historical manuscripts.

\section{Materials and methods}

\section{Samples resources}

All the historical parchments in this study were collected from differentinstitution, which contain a parchment manuscripts such as

1- Manuscripts store of the Egyptian Book House.

2- Manuscripts and Papyrus store in

Egyptian Book House.3- Papyrus and parchment store in Egyptian Book House.

4- Museum and manuscripts store in the library of the Egyptian Book House.

Stores of the National Archives and the institution of restoration of the National Archives.

4- Museum of manuscripts in Alexandria library.

5- Laboratory of manuscripts restoration in Central Institute for the Study ofBook Diseases in Rome, Italy.

\section{Samples isolation}

Forty historical parchments documents were analysed and studied but only twelve parchments are selected in this study based 
on the macroscopic observation like color change, water spots and parchment degradation (table 1) (morphological characteristics). Six out of 12 dated back from 2 to 4 Hijri, while three dated back to 697 to $760 \mathrm{Hijri}$ and three were unknown date. A new parchment was found infected due to bad conservations condition; therefore it was added to the historical parchmentsspecimen. The samples collection was done using sterile probact transport swabs (Technical service consultant Ltd), swabs collected across spots showing visible color change such as dark purple stains on several areas of the document and then used to inoculate Petri plates containing Sabouraud dextrose agar (Actidione ${ }^{\circledR}$ ) to obtaincultures suitable for fungal identification. Then, the petri-dish incubated at $25^{\circ} \mathrm{C}$ for 7 days, after that each petridish were purified on sabouraud agar tube (percentage of contamination was decreased on decreasing the surface of contact) to conserve all these specimen for others studies. The identification method was based on the morphological observation of the colony on the agar media and microscopic observation. 
INTERNATIONAL JOURNAL OF

MULTIDISCIPLINARY STUDIES IN ARCHITECTURE

AND CULTURAL HERITAGE

Table1: table showed the manuscripts included in this study and theirdescription.

\begin{tabular}{|c|c|c|c|}
\hline $\begin{array}{l}\text { Number } \\
\text { frestoration }\end{array}$ & Manuscripts & $\begin{array}{l}\text { Manuscripts } \\
\text { information }\end{array}$ & Description \\
\hline 668 & & $\begin{array}{l}\text { Marriage contract } \\
\text { dating back to the } \\
\text { 4th Hijri century } \\
\text { and was found in } \\
\text { the city of } \\
\text { Ashmounin. }\end{array}$ & $\begin{array}{l}\text { - Calcification dirty } \\
\text { - Water stains } \\
\text { - Dust on the surface } \\
\text { - Adhesive Scotch }\end{array}$ \\
\hline 670 & & $\begin{array}{l}\text { A marriag } \\
\text { econtract between } \\
\text { a couple dating } \\
\text { backto the 4th Hijri } \\
\text { century found in } \\
\text { the city of } \\
\text { Fayoum. }\end{array}$ & $\begin{array}{l}\text { - Corrosion stains } \\
\text { caused by the } \\
\text { active iron ink } \\
\text { - Dehydration. }\end{array}$ \\
\hline
\end{tabular}


INTERNATIONAL JOURNAL OF

MULTIDISCIPLINARY STUDIES IN ARCHITECTURE AND CULTURAL HERITAGE

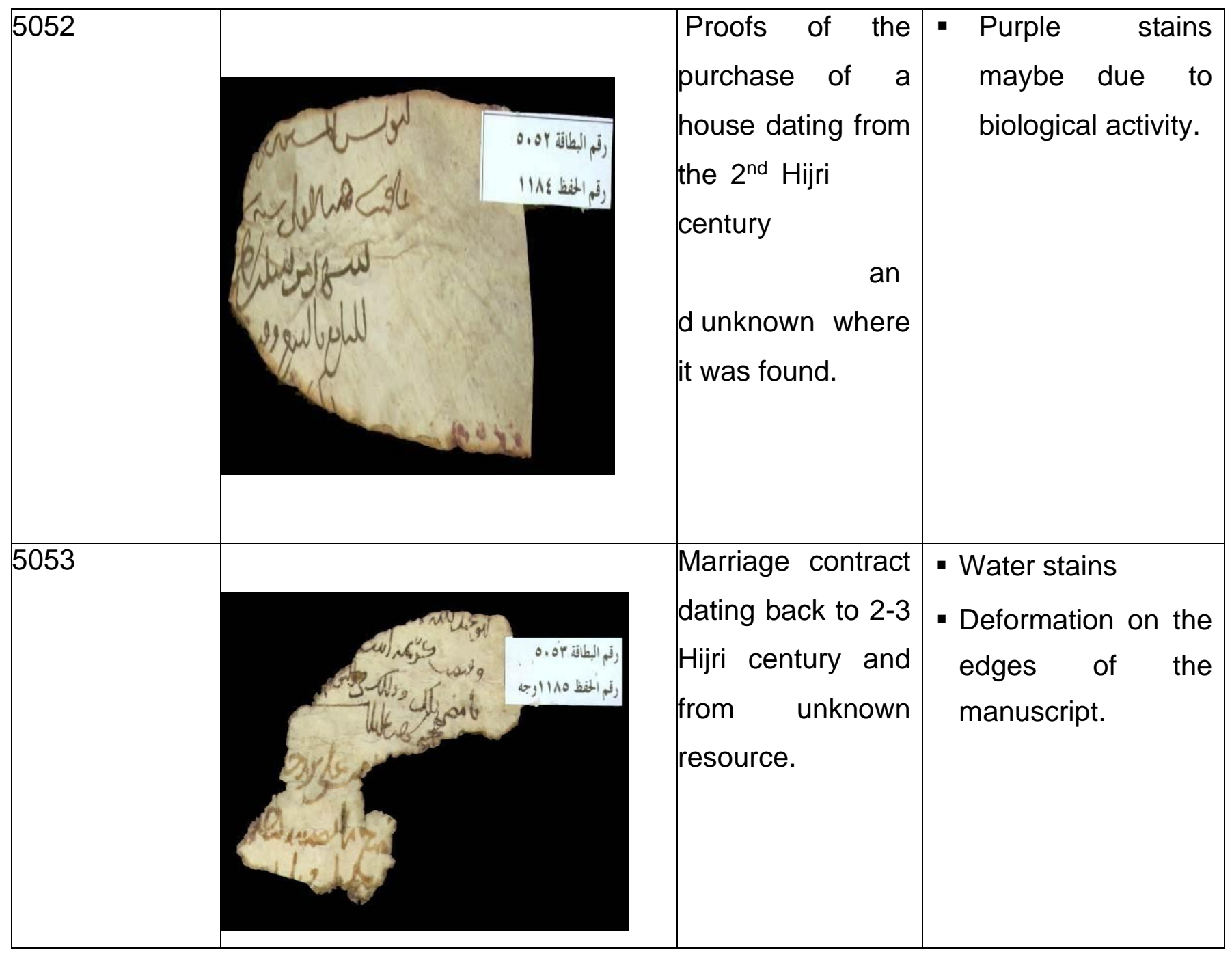


INTERNATIONAL JOURNAL OF

MULTIDISCIPLINARY STUDIES IN ARCHITECTURE

AND CULTURAL HERITAGE

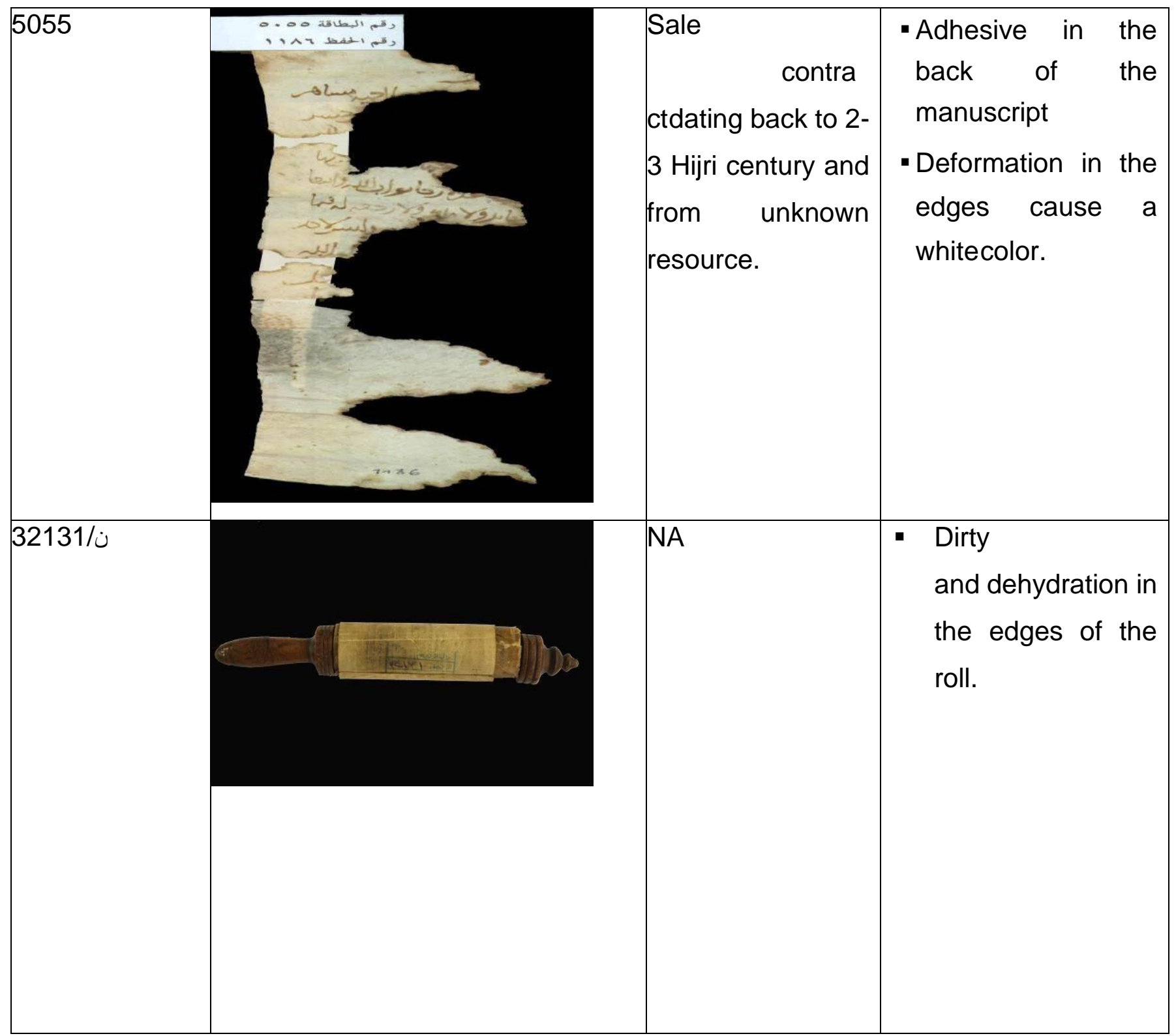


INTERNATIONAL JOURNAL OF

MULTIDISCIPLINARY STUDIES IN ARCHITECTURE AND CULTURAL HERITAGE

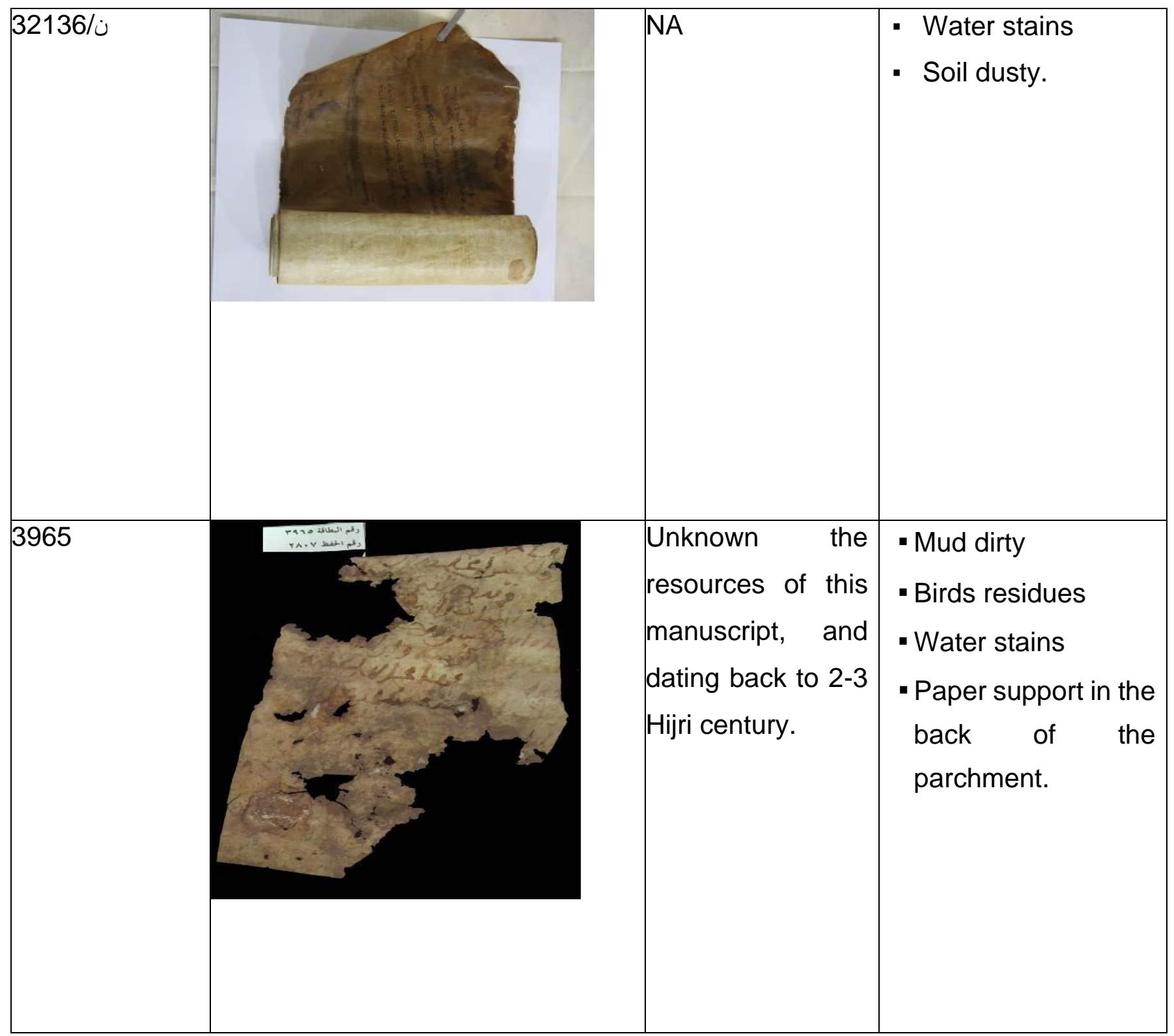


INTERNATIONAL JOURNAL OF

MULTIDISCIPLINARY STUDIES IN ARCHITECTURE AND CULTURAL HERITAGE

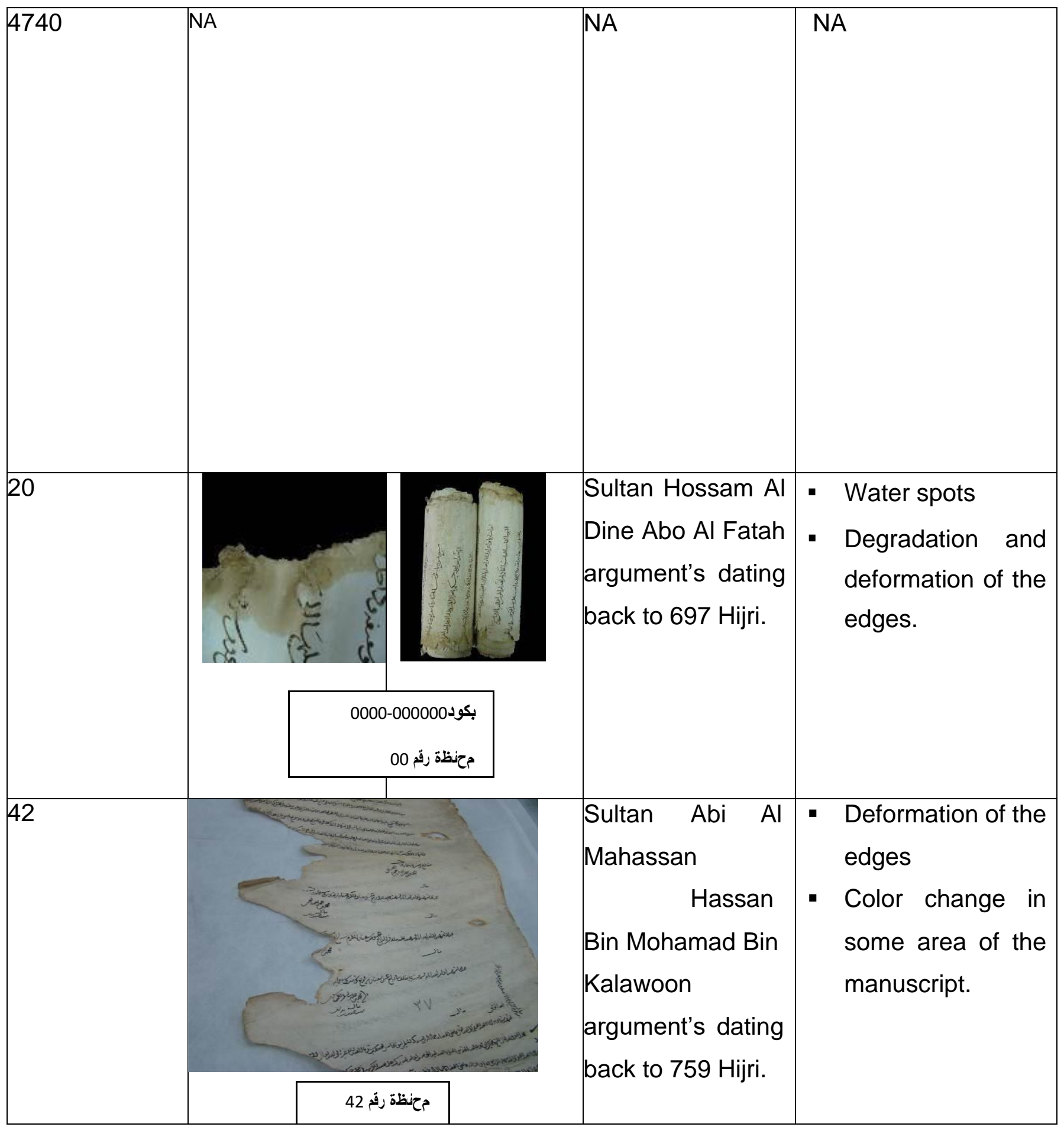




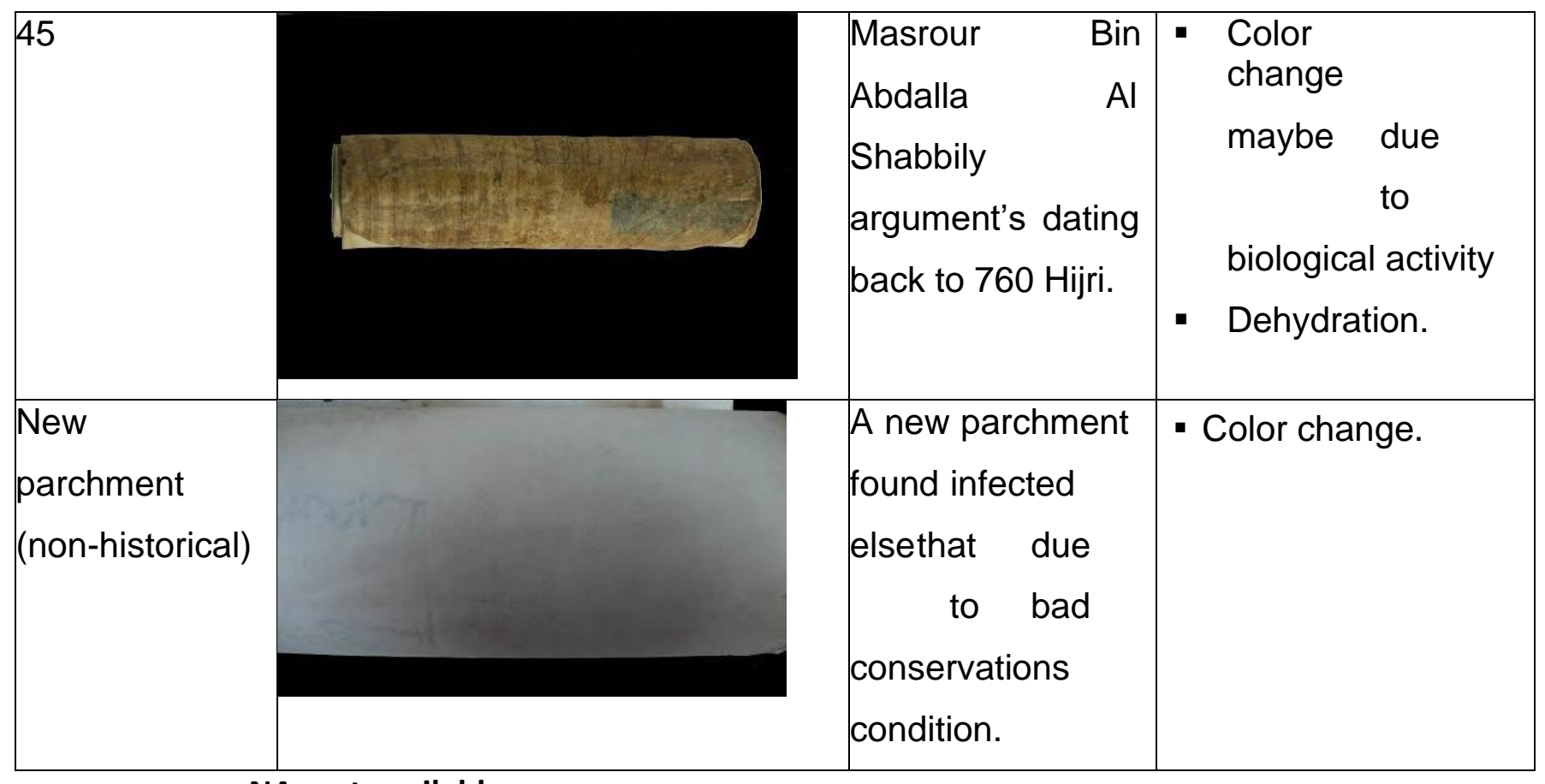

NA: not available

\section{Results and discussion}

Based on macroscopic (table 2) and microscopic observation (figure1), 4 genus of fungus are detected on parchments specimens, Aspergillus, Penicillium, Trichoderma and Phycomycetes. The first genus included 2 species of Aspergillus: niger and flavus, the others each genus included only one species Penicillium funiculosum, Trichoderma viride, and Phycomycetes. Eight of the twelve historical parchments have at least one active fungal infection.

Furthmore the new parchment infected else by 3 type. The nine (with the new one) parchments are showed in the table 2 with 


\section{AND CULTURAL HERITAGE}

the identification of the fungus species. The most common species of fungus that were identified in ours manuscripts are presented in figure 2. Overall, 16 isolates were identified in these manuscripts, which Aspergillus niger (6 isolates, 37.5\%) was the dominant species, followed by Aspergillus flavus ( 5 isolates, 31.25\%), Phycomycetes (3 isolates, 18.75\%), Trichoderma viride (1 isolates, 6.25\%), and Penicillium funiculosum (1 isolates, 6.25\%). These results are congruent with previous studies such as the study conducted by Megan Hempel et $a l(7)$ and PG Kalaskar et $a /(8)$, which both shown that the most common species identified in infected manuscripts were Aspergillus and Penicillium. In general, many studies showed that these two previous species were also more common in different manuscripts type like papers (8) and textiles (10).

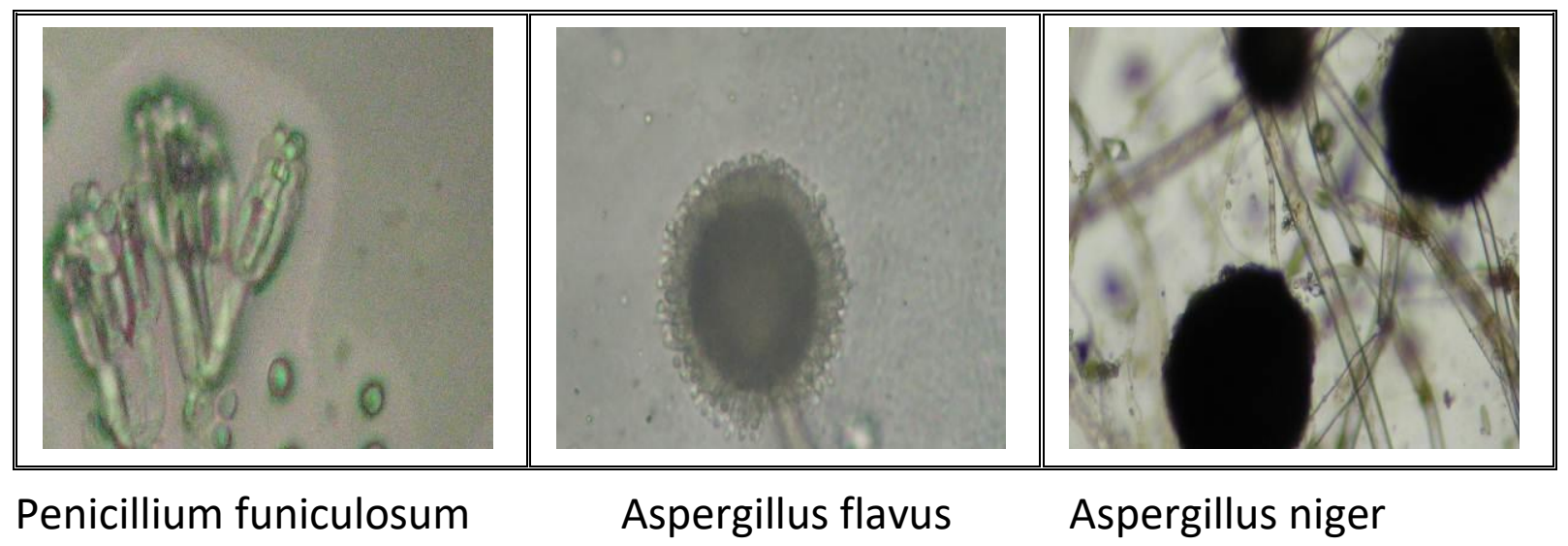


INTERNATIONAL JOURNAL OF

MULTIDISCIPLINARY STUDIES IN ARCHITECTURE

AND CULTURAL HERITAGE

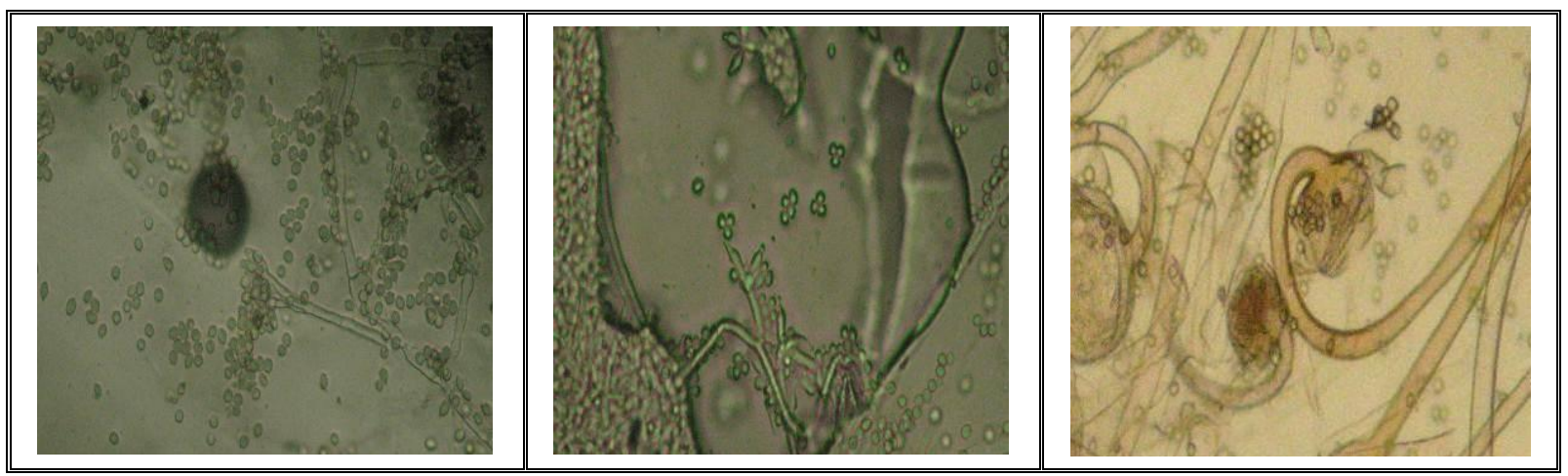

Penicillium funiculosum

Trichoderma viride

Phycomycetes

Figure1: figure showed the microscopic observation of each species detected in the infectedhistorical parchments.

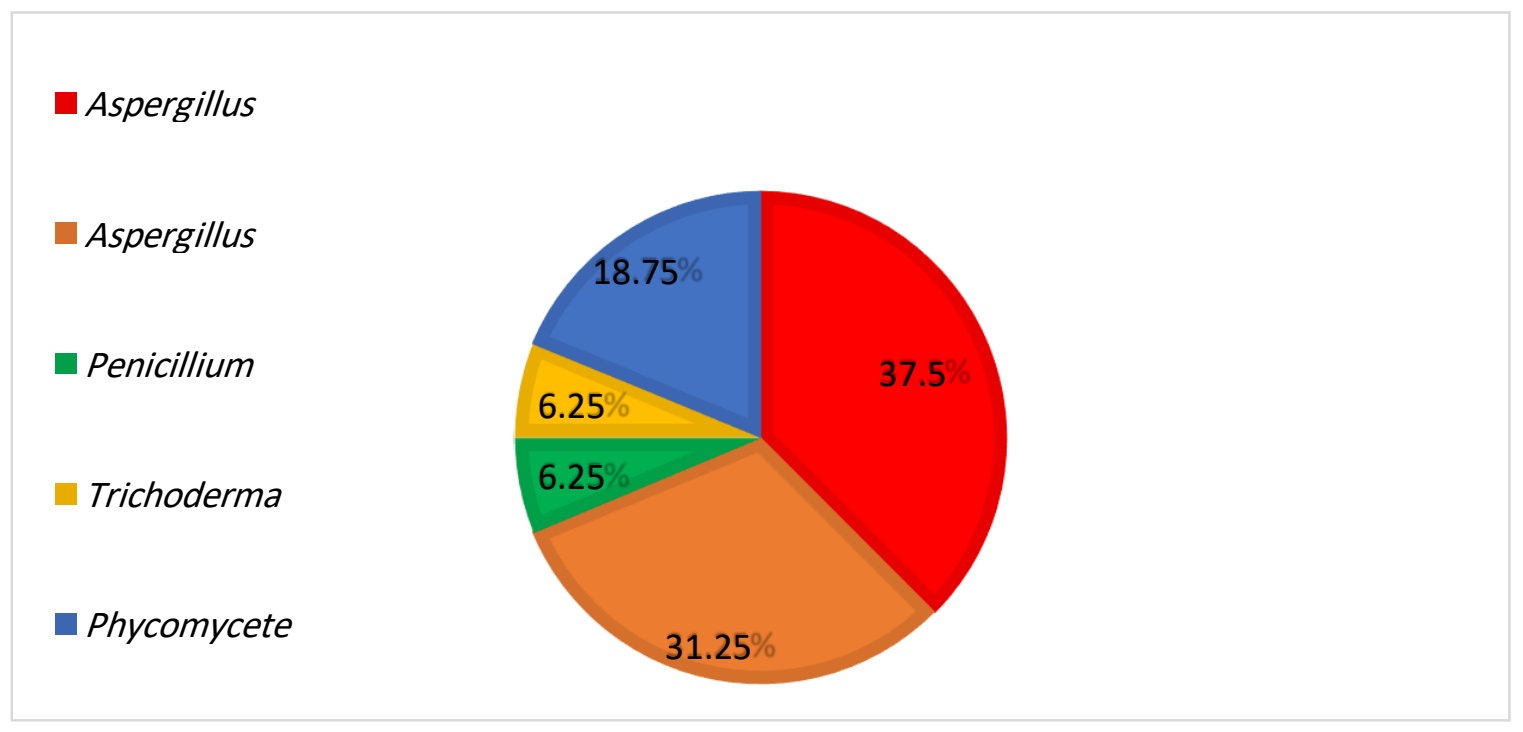

Figure 2: Percentage of identified species detected in the infected 
INTERNATIONAL JOURNAL OF

MULTIDISCIPLINARY STUDIES IN ARCHITECTURE AND CULTURAL HERITAGE

manuscripts.Table 2: the table showed the results of

parchments cultures.

\begin{tabular}{|c|c|c|}
\hline $\begin{array}{l}\text { Number of } \\
\text { restoration }\end{array}$ & $\begin{array}{ll}\text { Presence/absence } & \text { of } \\
& \text { fungal } \\
\text { infections } & \end{array}$ & Identification of fungus \\
\hline 668 & + & $\begin{array}{l}\text { Aspergillus } \\
\text { niger } \\
\text { Aspergillus } \\
\text { flavus }\end{array}$ \\
\hline 670 & - & \\
\hline 5052 & - & \\
\hline 5053 & - & \\
\hline 5055 & + & $\begin{array}{l}\text { Aspergillus } \\
\text { niger } \\
\text { Aspergillus } \\
\text { flavus }\end{array}$ \\
\hline ن32131 & - & \\
\hline ن32136 & + & Penicillium funiculosum \\
\hline 3965 & + & Trichoderma viride \\
\hline 4740 & + & $\begin{array}{l}\text { Aspergillus } \\
\text { niger } \\
\text { Aspergillus } \\
\text { flavus } \\
\text { Phycomycetes }\end{array}$ \\
\hline
\end{tabular}


INTERNATIONAL JOURNAL OF

MULTIDISCIPLINARY STUDIES IN ARCHITECTURE

AND CULTURAL HERITAGE

\begin{tabular}{|l|l|l|}
\hline 20 & + & $\begin{array}{l}\text { Aspergillus } \\
\text { niger } \\
\text { Aspergillus } \\
\text { flavus }\end{array}$ \\
\hline 42 & + & Aspergillus niger \\
\hline 45 & + & Phycomycetes \\
\hline The ne & + & $\begin{array}{l}\text { Aspergillus } \\
\text { niger } \\
\text { Phycomycetes } \\
\text { Aspergillus } \\
\text { flavus }\end{array}$ \\
\hline
\end{tabular}

Presence: +, Absence: -

\section{Conclusion:}

In these days, there are many unique and valuable manuscripts that are exposed to a high risk of damage because of the inappropriate storage, inadequate climate conditions, and improper handling. All these previous conditions could be an essential cause for creation a good media for microorganisms' developments, therefore preventive action should be taken to protect this heritage for the next generations. This study identified the type of fungus that caused infection and damage for eight historical parchments in different institution that contains rare and historical manuscripts, which Aspergillus niger was the dominant species, followed by Aspergillus flavus, Phycomycetes, Trichoderma viride, and Penicillium funiculosum. 
INTERNATIONAL JOURNAL OF

MULTIDISCIPLINARY STUDIES IN ARCHITECTURE

AND CULTURAL HERITAGE

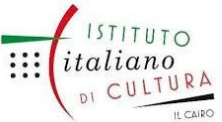

New perspectives will be addressed in the future:

- The use of a molecular identification method for these fungi such as PCR andsequencing.

- Studying the mechanical characteristic of these fungal infections on thecomponents of the parchment and their influence on its elasticity.

- The use of different cleaning method to eliminate the effect of fungus onparchment manuscripts.

\section{Refrences}

1. Facchini A, Malara C, Bazzani G, Cavallotti PL. Ancient Parchment Examination by Surfacelnvestigation Methods. Vol. 231. 2000. 213 p.

2. Troiano F, Polo A, Villa F, Cappitelli F. Assessing the microbiological risk to stored sixteenthcentury parchment manuscripts: a holistic approach based on molecular and environmental studies. Biofouling. 2014;30(3):299-311.

3. Mož ir A, Cigić IK, Marinšek M, Strlič M. Material properties of historic parchment: Areference collection survey. Stud Conserv. 2014 May 1;59(3):136-49.

4. Sawoszczuk T, Syguł a-Cholewiń ska J, Del Hoyo-Meléndez JM. Application of HS-SPME-GC-MS method for the detection of active moulds on historical parchment. Anal Bioanal Chem. 2017 Mar;409(9):2297-307.

5. Boyatzis SC, Velivasaki G, Malea E. A study of the deterioration of aged parchment markedwith laboratory iron gall inks using FTIR-ATR spectroscopy and micro hot table. Herit Sci. 2016 May 11;4(1):13.

6. Pinzari F, Colaizzi P, Maggi O, Persiani AM, Schütz R, Rabin I. Fungal bioleaching of mineralcomponents in a twentieth-century illuminated parchment. Anal Bioanal Chem. 2012 Feb;402(4):1541-50. 
INTERNATIONAL JOURNAL OF

MULTIDISCIPLINARY STUDIES IN ARCHITECTURE

AND CULTURAL HERITAGE

7. Hempel M, Rakhra V, Rothwell A, Song D. Bacterial and fungal contamination in the librarysetting: a growing concern? Environ Health Rev. 2014 Mar 1;57(01):9-15.

8. Biodeterioration of Library Resources and Possible Approaches for their Control - Google Search [Internet]. [cited 2019 Mar 5]. Available from: https://www.google.com/search?q=Biodeterioration+of+Library+Resource stand+Possible+Ap proaches+for+their+Control\&oq=Biodeterioration+of+Library+Resources+a nd+Possible+Appr oaches+for+their+Control\&aqs=chrome..69i57j69i60.1444j0j7\&sourceid=c hrome\&ie=UTF-8.

9. Lech T. Evaluation of a Parchment Document, the 13th Century Incorporation Charter for theCity of Krakow, Poland, for Microbial Hazards. Appl Environ Microbiol. 2016 May;82(9):2620-31.

10. Abdel-Kareem O. Evaluating the combined efficacy of polymers with fungicides for protection of museum textiles against fungal deterioration in Egypt. Pol J Microbiol. 2010;59(4):271-80. 